\title{
The Suitability of Mangrove Ecotourism Based on Its Biophysical Condition in Hamadi Beach, Jayapura City
}

\author{
Annisa Novita Sari*, Chandra Bhaskara, Aldi Bimantara \\ Department of Urban and Regional Planning, Faculty of Engineering, Cenderawasih University
}

\begin{abstract}
Mangrove ecotourism is one of the potential sustainable tourism practice in which it is important to support local economic development and mangrove conservation. The purpose of this research is to identify the potential of natural resources in supporting mangrove ecotourism on the coast of Hamadi Beach, Jayapura City and to analyze the suitability of mangrove ecotourism land on the coast of Hamadi Beach, Jayapura City. The method used in this study is a survey method. The survey was conducted to see the biophysical condition of mangrove forests, which include mangrove length, mangrove density, mangroves species and biota species. Then, the biophysical data will be analyzed with Ecotourism Suitability Index (ESI). The survey results showed that the average mangroves' length was 254 meters, the average mangrove density of 12,367 individuals.ha-1. Mangrove species found included Avicennia alba, Avicennia lanata, Avicennia marina, Acrostichum speciosum, Bruguiera sexangula, Rhizopora apiculata, Rhizopora mucronata, Rhizopora stylosa, and Sonneratia alba. The types of biota found consisted of birds, reptiles, amphibians, molluscs, crustaceans, and insects. The results of the suitability index of mangrove ecotourism obtained the Ecotourism Suitability Index (ESI) value of $77.78 \%$. This study concludes that the mangrove forest area in Hamadi Beach is very suitable for ecotourism areas. Therefore, it is suggested to make a good and environmentally friendly ecotourism arrangement concept, so the community can travel while learning in the mangrove ecosystem area in Hamadi Beach.
\end{abstract}

Keywords: Ecotourism, Hamadi Beach, mangrove forest.

\section{INTRODUCTION}

Indonesia is a country that has great natural tourism potential with abundant natural resources. The potential of natural resources owned, both on land and ocean can be developed into educational tourism. One city that has great natural potential is Jayapura City. Jayapura City is one of the areas located on the coast of the sea with abundant natural resources.

One of the natural potential owned by Jayapura City is Mangrove Forest. There are many functions of Mangrove Forest, one of them is for recreation and tourism [1]. Mangrove forests in Jayapura City are found in Youtefa Bay, which one of them is found on Hamadi Beach. The Jayapura City Government has established the mangrove forest on Hamadi beach as a natural tourism park. The Regional Regulation of Jayapura City No. 1 of 2014 about Spatial Planning for 2013 - 2033 Article 45 states that the natural tourism park area in Jayapura City with an area of $308 \mathrm{Ha}$ in the form of Youtefa Bay Natural Park, located in South Jayapura District, Abepura District, and Muara Tami District. Based on the Jayapura Regional Regulation No. 6 of 2010 about Spatial Planning Detail of South Jayapura District, is stated that the

*Correspondence address:

Annisa Novita Sari

Email : annisanovita118@gmail.com

Address : Jl. Kamp Wolker, Jl. Kambolker Perumnas III,

Yabansai, Heram, Jayapura City, Papua 99224 Cenderawasih University natural tourism park and marine natural park located in Youtefa Bay are designated as the Natural Reserve Area.

Indonesian Ministry of Forestry Regulation No. P.49/Menhut-II/2014 about Function Suitability Assessment Procedures of Natural Reserves Areas and Natural Conservation Areas states that Natural Reserve Areas are areas with certain characteristics, both on land and waters that have a primary function as a conservation area of biological and animals biodiversity and their ecosystems which also function as areas for life support systems. Referring to this regulation, the mangrove forest area in Hamadi Beach, which functions as a Natural Reserve Area, must always be maintained so that its function as a life buffer can be saved.

However, problems that threatened the existence of mangrove forests in the Youtefa Bay natural tourism park began to occur. The problem is the degradation of mangrove forest. The mangrove area in Youtefa Bay in 2017 was 233.12 $\mathrm{Ha}$, which decreased by $8.12 \mathrm{Ha}$ compared to the mangrove area in 2008. It was caused by the opening of mangrove land for development roads, bridges, and residential areas. Also, the community uses it for household purposes [2].

The problem of mangrove forest degradation is still possible to continue to occur because physical development is still ongoing, especially in the coastal areas of Jayapura City. That's why the pressure on the coastal areas of Jayapura City will 
always be increase. To respond to the existing problems, the City Government gave a discourse to make the mangrove forest area in Youtefa Bay, especially on Hamadi Beach, as an ecotourism area with the aim that the existence of mangrove forests will continue saved. Ecotourism is defined as responsible travel to natural areas that conserves the environment, sustains the wellbeing of the local people, and involves interpretation and education [3].

Therefore, it is necessary to study the suitability of mangrove forests in Hamadi Beach as an ecotourism area based on the natural resources potential of mangrove forests so that the existing ecotourism management can be sustainable later. The indicators of suitability for land ecosystems consist of landscape/naturalness, wildlife, topography, accessibility, and community characteristics [4]. So, the purposes of this study are to identify the potential of natural resources in supporting mangrove ecotourism on Hamadi Beach, Jayapura City, also to analyze the suitability of the mangrove ecotourism land on Hamadi Beach, Jayapura City.

\section{MATERIAL AND METHOD}

\section{Study Area}

This research focused on mangrove forests located on Hamadi Beach, Jayapura City (Fig. 1). The selection of research location is based on the Jayapura City Government's plan to make the mangrove forest in Hamadi Beach as an ecotourism area. Based on the Jayapura City Government's plan, it is necessary to study the suitability of mangrove forest land as an ecotourism area based on the potential of natural resources owned by mangrove forests in the Hamadi Beach. The research was conducted in March - August 2019.

\section{Type of Research}

The type of this research is quantitative descriptive with survey method. The survey method is an investigation to obtain the facts from the existing symptoms and look for factual information from a group or an area [5]. The survey of this research was conducted to see the ecological condition of mangrove forest, which includes thickness, the density of mangroves, types of mangroves, and types of mangrove biota.

\section{Data Collection}

Data collection techniques of this research are observation, interview, and documentation. The observation is data collection about the biological condition of mangrove forests includes mangrove density, mangrove types, and biota types in the mangrove forest. The interview is data collecting about mangrove conditions. Documentation is data collection in the form of documents or research supporting data that have been collected by the relevant agencies. The supporting documents include Jayapura City Spatial and Regional Planning (RTRW), the profile of South Jayapura District, and tidal data.

\section{Data Processing}

Mangrove Density

Data collection of mangrove density was carried out with the following steps.

1) Determine the observation stations using line transects along the coastline, where 3 (three) observation sites are determined (Fig. 1.)

2) Each observation station was made of $10 x$ $10 \mathrm{~m}^{2}$ of square transect, which was placed perpendicular to the coast to the mainland with three plots.

3) In each plot, determined of each mangrove and counted the number of each species, and measured the stem circle of each mangrove tree at breast height.

4) Furthermore, the results of the calculation of mangrove species are calculated using the formula:

$$
\text { Density }=\frac{\text { Number of each species }}{\text { Area of plot }}
$$

\section{Identification of Mangrove Species}

The types of mangrove identified based on mangrove stands that enter the square transect. The sample of each mangrove species was taken and identified in the laboratory to determine the type of mangrove.

\section{Identification of Biota Species}

Biota data collection was done using visual methods. Biota was observed directly at each sampling site, taken using a scoop and gill net. Biota taken was photographed and identified using an identification book.

1) Fish sampling is using a gill net to catch fish. Then, it was photographed and analyzed its species.

2) Sampling of birds and insects was carried out by direct observation at each site. Every bird and insect that perched on the mangrove tree was photographed and analyzed for its species.

3) Sampling of Mollusca and crustaceans is done by taking biota directly on the 
substrate, separating it from the substrate, and analyzing its species. In addition, interviews were also conducted with local fishermen on the species of shellfish that were caught.

4) Sampling of reptiles and amphibians were taken by direct observation of each species of reptile and amphibian in each sampling plot.
Identification of Tides and Mangrove Suitability for Ecotourism

Tidal data is collected from Navy of Jayapura City. The suitability mangrove as ecotourism is calculated by considering five parameters. mangrove length $(\mathrm{m})$, mangrove density (ind.ha ${ }^{-1}$ ), mangrove species, tidal $(\mathrm{m})$, and biota (Table 1 ) [6].

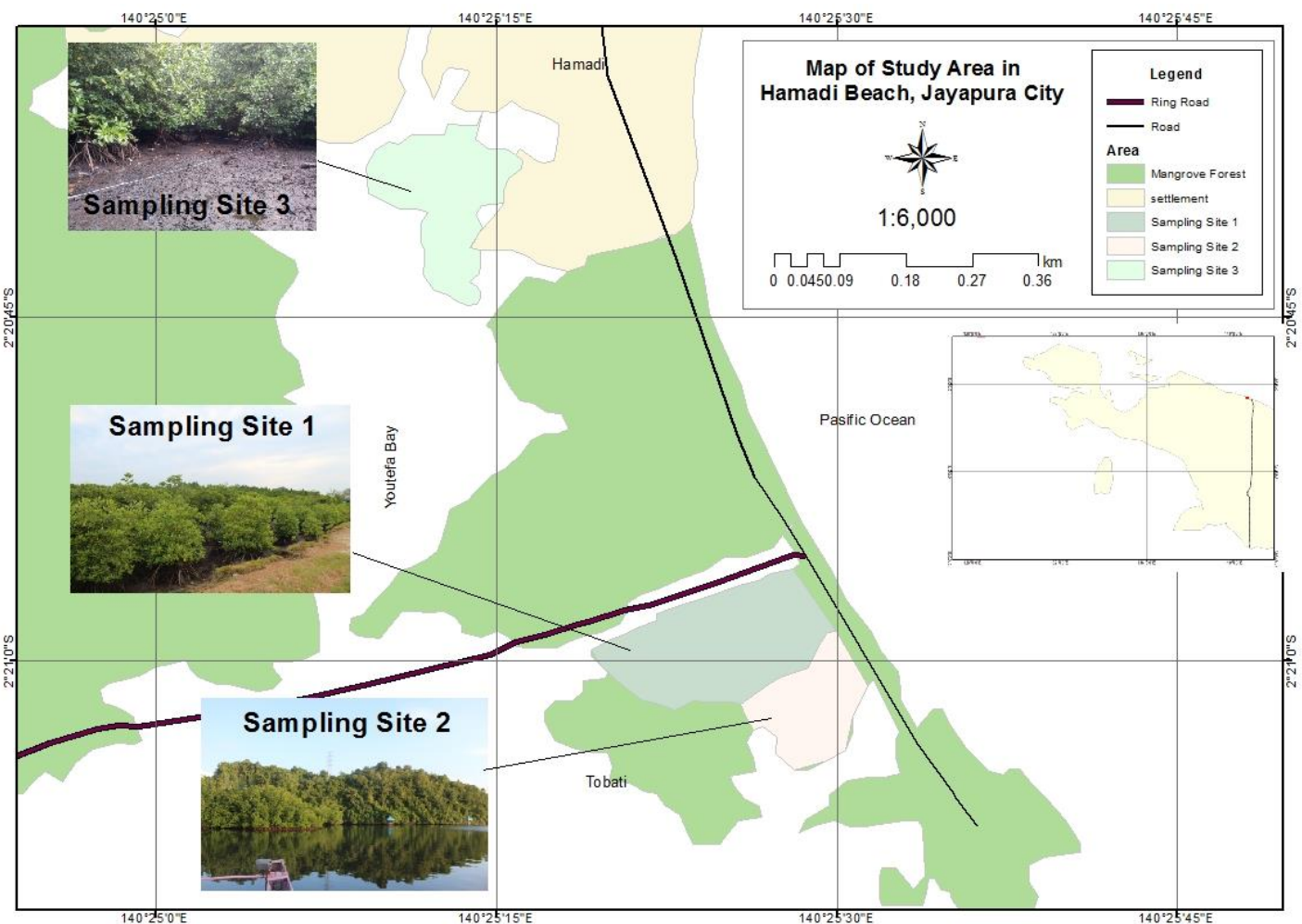

Figure 1. Map of Study Area and Selected Sampling Sites in Hamadi Beach, Jayapura City (Source: Result Analysis, 2019)

Table 1. Matrix of Land Suitability for Ecotourism

\begin{tabular}{|c|c|c|c|c|c|c|c|c|c|}
\hline \multirow[b]{2}{*}{ Parameters } & \multirow[b]{2}{*}{ Weight } & \multicolumn{8}{|c|}{ Class of suitability (score) } \\
\hline & & $\begin{array}{l}\text { S1 (very } \\
\text { suitable) }\end{array}$ & Score & S2 (suitable) & $\begin{array}{c}\text { Scor } \\
\text { e }\end{array}$ & $\begin{array}{c}\text { S3 (conditional } \\
\text { suitable) }\end{array}$ & Score & $\begin{array}{c}\mathbf{N} \text { (not } \\
\text { suitable) }\end{array}$ & Score \\
\hline $\begin{array}{l}\text { Mangrove } \\
\text { Length (m) }\end{array}$ & 5 & $>500$ & 3 & $>200-500$ & 2 & $50-200$ & 1 & $<50$ & 0 \\
\hline Mangrove & & & & & & & & & \\
\hline $\begin{array}{l}\text { Density } \\
\text { (ind.100 } \mathrm{m}^{-2} \text { ) }\end{array}$ & 3 & $>15-25$ & 3 & $>10-15$ & 2 & $5-10$ & 1 & $<5$ & 0 \\
\hline $\begin{array}{l}\text { Mangrove } \\
\text { Species }\end{array}$ & 3 & $>5$ & 3 & $3-5$ & 2 & $1-2$ & 1 & 0 & 0 \\
\hline Tidal (m) & 1 & 0,1 & 3 & $>1-2$ & 2 & $>2-5$ & 1 & $>5$ & 0 \\
\hline Biota & 1 & $\begin{array}{c}\text { Fish, Shrimp, } \\
\text { Crab, } \\
\text { Mollusca, } \\
\text { Reptil, Aves }\end{array}$ & 3 & $\begin{array}{c}\text { Fish, Shrimp, } \\
\text { Crab, } \\
\text { Mollusca }\end{array}$ & 2 & Fish, Mollusca & 1 & $\begin{array}{l}\text { One of } \\
\text { the } \\
\text { water } \\
\text { biota }\end{array}$ & 0 \\
\hline
\end{tabular}

Source: Yulianda [6] 
To count the suitability index of mangrove ecotourism with the formula:

$$
E S I=\left(\frac{\sum N i}{N \max }\right) \times 100 \%
$$

Description:

$$
\begin{array}{ll}
\mathrm{ESI} & =\text { ecotourism suitability index } \\
\mathrm{Ni} & =\text { parameter value to- } i \text { (weight } \times \text { score) } \\
\mathrm{N} \text { maks } & =\text { maximum value of tourism categories }
\end{array}
$$

The suitability land level divided into four classifications [6]:

$$
\begin{aligned}
& \text { S1 }=\text { very suitable }(\text { ESI } 75-100 \%) \\
& \text { S2 }=\text { suitable (ESI } 50-74 \%) \\
& \text { S3 }=\text { conditional suitable }(\text { ESI } 25-49 \%) \\
& N=\text { not suitable }(E S I<25 \%)
\end{aligned}
$$

\section{Data Analysis}

Data analysis used in this research is quantitave descriptive. This analysis to describe the real condition of research location based on data processing that has been done.

\section{RESULTS AND DISCUSSIONS \\ General Descriptions of Research Location}

Mangrove forests along the Hamadi Beach are administratively included in the area of Tobati Village, South Jayapura District, Jayapura City. Tobati Village is located in South Jayapura District, with an area of $2.5 \mathrm{~km}^{2}$. The entire location of Tobati Village is a settlement that is above sea level and has a tropical climate with moderate rainfall. The distance of Tobati Village to the business centers (markets and shops) is less than $1 \mathrm{~km}(650 \mathrm{~m})$ by using the sea transportation system (speed boat or johnson motorboat, katinting motorboat and traditional boats to get to the beach or community pier. Furthermore, using land transportation with the 2-wheeled vehicles or 4-wheeled vehicles around 5-10 minutes. Tobati Village is one of two villages that are included in the administrative region of South Jayapura District, Jayapura City, where the Government of Tobati Village is in charge of three Neighborhoods and one Hamlet. The administrative boundaries of Tobati Village are as follows.

$$
\begin{array}{ll}
\text { East side } & \text { : Pacific Ocean } \\
\text { West side } & \text { : Entrop Village } \\
\text { Southern side } & \text { Enggros Village } \\
\text { North side } \quad \text { : Hamadi Village and Argapura Village }
\end{array}
$$

\section{Tourism Potential}

The tourism potential owned by Tobati Village is quite large. Tobati Village is a coastal area of Yotefa Bay, a part of which is heavily populated by mangroves. Also, some plants grow and species of animals and poultry that live in rock/coral mountains that surround the waters of the Tobati village. If the water recedes, the soil conditions look like silt mixed with sand and a lot of seaweed growing. In addition, on the west bank of Tobati village, a ring road has been made which connects the South Jayapura District and the Abepura District. East of Tobati Village, Youtefa Bridge has also been built, which connects South Jayapura District with Muara Tami District.

\section{Natural Resources Potential Mangrove length}

Based on the measurement results, mangrove length is on an average of $254 \mathrm{~m}$. The thickness of the mangroves in each sampling station showed in Figure 2. At Station I, the length of the mangrove was $352 \mathrm{~m}$. The length of the mangrove at Station I is greater compared to other stations. The mangrove length at Station II and III is $200 \mathrm{~m}$ and $210 \mathrm{~m}$, respectively. Mangroves in Station II and III close to residential areas, thus mangroves in Station II and III is directly affected by land conditions. Mangrove length has an impact on the ecological aspects of the substrate and coastal biota. The higher length of mangroves causes high amounts of organic matter in the substrate and the density of macrobenthos and plankton. Besides that, the mangrove length can also affect the salinity of groundwater around mangrove forests [7].

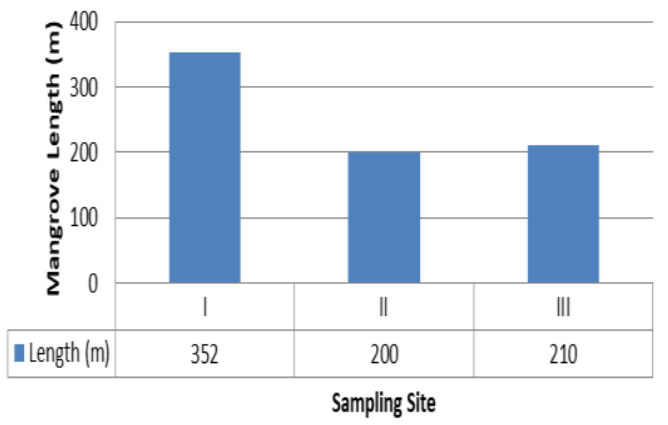

Figure 2.Mangrove Length for each sampling site on Hamadi Beach, Jayapura City (Source: Result Analysis, 2019)

The Species of Mangrove

Based on identification results, there are four mangrove families, namely Avicenniaceae, Pteridacea, Rhizophoraceae, and Sonneratiaceae. The species of mangrove found at the study site were nine species including Avicennia alba, A. lanata, A. marina, Acrostichum speciosum, Bruguiera sexangula, Rhizopora apiculata, $R$. mucronata, R. stylosa and Sonneratia alba (Table 2). Rhizopora sp. is the dominant spesies on research sites. Rhizopora sp. stretches throughout the Asian region [8]. 
The diversity of mangrove species can be a tourist attraction. Mangrove diversity can be used as a choice for tourists to enjoy the natural beauty of mangroves, while also increase knowledge about the environment and the importance of mangrove ecosystems in the structural coastal ecosystem [9].

Table 2. The Species of Mangrove on Hamadi Beach

\begin{tabular}{cllll}
\hline \multirow{2}{*}{ No. } & \multirow{2}{*}{ The Species of Mangrove } & \multicolumn{3}{c}{ Sampling Site } \\
\cline { 3 - 5 } & & I & II & III \\
\hline 1. & Avicennia alba & + & - & - \\
2. & Avicennia lanata & + & - & - \\
3. & Avicennia marina & + & - & - \\
4. & Acrostichum speciosum & + & - & - \\
5. & Bruguiera sexangula & + & + & + \\
6. & Rhizopora apiculata & - & + & + \\
7. & Rhizopora mucronata & + & + & + \\
8. & Rhizopora stylosa & - & + & - \\
9. & Sonneratia alba & + & - & - \\
\hline
\end{tabular}

Source: Observation Results, 2019

\section{Mangrove Density}

Mangrove density is measured through a comparison between the number of individuals found in the sample plot and the area of the sample plot, expressed in ind.ha- ${ }^{-1}$. The largest mangrove density is 15,300 ind $^{-h} \mathrm{a}^{-1}$ at Site I, then followed by Site II for 12,700 ind.ha ${ }^{-1}$ and Site III for 9,100 ind.ha ${ }^{-1}$. Thus, the total mangrove density in Hamadi Beach is 37,100 ind.ha ${ }^{-1}$, with an average of 12,367 ind.ha $^{-1}$ (Fig. 3). Refer to the Decree of the Environment Minister, Number 201 of 2004 concerning the Criteria Standard for Mangrove Damage, the mangrove forests in Hamadi Beach are considered good and very dense.

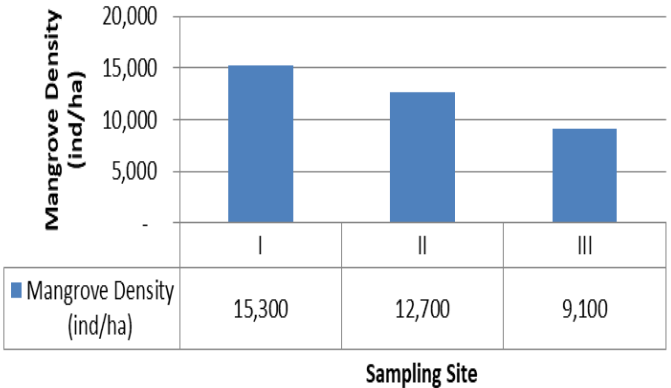

Figure 3. Mangrove Density for each sampling site on Hamadi Beach Jayapura City (Source: Results Analysis, 2019)

Tidal

Tidal measurement data at the study area using tidal signs at coordinates $\mathrm{S}=02^{\circ} 32^{\prime} 23^{\prime \prime}$ and E $140^{\circ} 42^{\prime} 24^{\prime \prime}$ obtained from the Navy database in 2018. Tidal data were calculated from December 1st to December 31st, 2018. Based on available data, it is known that the highest water level is $1.4 \mathrm{~m}$, and the lowest water level is $0.1 \mathrm{~m}$, with an average of $0.75 \mathrm{~m}$. Type of tides in the study area is classified as Diurnal Tides.

\section{Types of Biota}

The types of biota found on Hamadi Beach, Jayapura City are fishes, birds, reptiles, amphibi, mollusca, crustacean, and insect (Table 3). All types of biota were found at all of the sampling sites. Biota found in mangrove forests can also be a tourist attraction [7]. So, the diversity of biota species in the area of mangrove forests in Hamadi Beach can also be a tourist attraction if the mangrove forest is used as an ecotourism area.

Table 3. Types of Biota in Mangrove Forest on Hamadi Beach, Jayapura City

\begin{tabular}{|c|c|c|c|c|c|c|}
\hline \multirow{2}{*}{ No. } & \multirow{2}{*}{ Biota } & \multirow{2}{*}{ Spesies } & \multirow{2}{*}{ Local Name } & \multicolumn{3}{|c|}{ Sampling Site } \\
\hline & & & & I & II & III \\
\hline \multirow{4}{*}{1.} & \multirow{4}{*}{ Fish } & Periophthalmus modestus & Mudskiper & + & + & - \\
\hline & & Anabas testudineus & Climbing Gouramy & - & + & + \\
\hline & & Gemiramphus brasiliensis & Ballyhoo halfbreak & + & - & + \\
\hline & & Chanos chanos & Milkfish & + & - & + \\
\hline \multirow{4}{*}{2.} & \multirow{4}{*}{ Aves } & Laridae sp. & Gulls & + & + & - \\
\hline & & Ephippiorhynchus asiaticus & Black Necked Stork & + & + & - \\
\hline & & Sterna bengalensis & Lesser Crested Tern & + & + & - \\
\hline & & Ciconia ciconia & White Stork & - & - & + \\
\hline \multirow{2}{*}{3.} & \multirow{2}{*}{ Reptile } & Varanus salvator & Monitor Lizard & - & + & - \\
\hline & & Mabouya spp. & Lizard & + & + & + \\
\hline 4. & Amphibi & Rana cancrivora & Crab-eating Frog & + & + & + \\
\hline \multirow{3}{*}{5.} & \multirow{3}{*}{ Mollusca } & Polymesoda erosa & Young Clam & + & + & + \\
\hline & & Polymesoda coaxan & Mangrove Clam & + & + & + \\
\hline & & Octopus sp. & Octopus & + & + & + \\
\hline \multirow{2}{*}{6.} & \multirow{2}{*}{ Crustacea } & Scylla sp. & Mangrove Crab & + & - & + \\
\hline & & Thalassina anomala & Mud Lobster & + & + & - \\
\hline 7. & Insect & Papilionidae sp. & Butterfly & + & + & + \\
\hline
\end{tabular}




\section{Ecotourism Suitability Analysis of Mangrove Forest}

Based on the vegetation condition of mangrove forests, the ecotourism suitability of mangrove forest was analyzed. The ecotourism suitability level of mangrove forests is assessed based on Yulianda [6].

In Table 4, it is known that the highest ESI value is in Site I that is $87.18 \%$, then followed by Site III for $79.49 \%$, while the lowest is in Site II for $66,67 \%$. The average value of the three sites is $77.78 \%$, so that the mangrove forest area in Hamadi Beach, Jayapura City, is included in the very suitable category to be used as an ecotourism area. It is supported by the ecological condition of mangroves that are still very good with high mangrove density, length of mangroves that are still good, and a large diversity of mangrove species. Also, the diversity of biota is very supportive, where we found seven types of biota in the mangrove forest of Hamadi Beach. The tidal height is also suitable for supporting mangrove life so that mangrove plants in the Hamadi Beach area can grow optimally.

Table 4. Ecotourism Suitability Index (ESI) of Mangrove Forest on Hamadi Beach, Jayapura City

\begin{tabular}{llll}
\hline No. & Station & ESI & Information \\
\hline 1. & Station I & $87.18 \%$ & Very suitable \\
2. & Station II & $66.67 \%$ & Suitable \\
3. & Station III & $79.49 \%$ & Very suitable \\
\hline
\end{tabular}

Source: Analysis Result, 2019

Ecotourism is natural tourism, which contributes to social and environmental benefits [10]. In addition, ecotourism also has economic benefits by increasing regional revenue annually $[11,12]$. With these benefits, we must manage ecotourism well and sustainably so that these benefits can be obtained continuously.

Ecotourism efforts must provide economic incentives for conservation, empowering the local community, and environmental awareness. There are several components to develop the strategy of sustainable ecotourism [13-15], namely:

- Respect and care to the environment;

- Rationalizing the exploitation of nonrenewable resource;

- Conservation of ecosystem and biodiversity;

- Provide opportunities for the community to manage their environment.

\section{CONCLUSION}

Potential natural resources found in Hamadi Beach are mangrove forests, where mangrove length is on average $254 \mathrm{~m}$, mangrove density is high with an average of 12,367 ind.ha ${ }^{-1}$, and mangrove species found in nine species. Other potential natural resources found are biota, which consists of fish, birds, reptiles, amphibians, mollusca, crustaceans, and insects. Mangrove forests in Hamadi Beach are very suitable to be designated as ecotourism areas. With ESI value of $77.78 \%$, they are categorized as S1 or very suitable.

\section{REFERENCES}

[1] Spalding, M. and C. L. Parret. 2019. Global patterns in mangrove recreation and tourism. Journal Marine Policy 110, 1-8.

[2] Hamuna, B., A. N. Sari, and R. Megawati. 2018. The condition of mangrove forests in Youtefa Bay Natural Park, Jayapura City. Biology Scientific Magazine BIOSFERA: A Scientific Journal 35(3), 75-83.

[3] The International Ecotourism Society (TIES). 2019. What is ecotourism? Available at: https://ecotourism.org/what-isecotourism/.

[4] Bunruamkew, K. and Y. Murayama. 2011. Site suitability evaluation for ecotourism using GIS \& AHP: a case study of Surat Tani Province, Thailand. Procedia Social and Behavioral Science 21, 269-278. DOI: 10.1016/j.sbspro.2011.07.024

[5] Nazir, M. 2005. Research method. Ghalia Indonesia. Bogor.

[6] Yulianda, F. 2007. Marine ecotourism as an alternative use of conservation-based coastal resources. Science Seminar Paper. Department of Water Resource Management. Faculty of Fisheries and Marine Science. Bogor Agricultural University. Bogor.

[7] Latupapua, Y. T., R. Loppies, and F. D. S. Fara. 2019. Mangrove suitability analysis as an object of ecotourism attraction in Siahoni Village, Buru Utara Timur Regency, Maluku Province. Sylva Lestari Journal 7(3), 267-276.

[8] Mauludin, M. R., R. Azizah, R. Pribadi and Suryono. 2018. Composition and cover of mangrove canopies in the Ujung Piring Area of Jepara Regency. Marina Oceanographic Bulletin 7(1), 29-36.

[9] Sadik, M., A. H. Muhidin and M. Ukkas. 2017. The suitability mangrove ecotourism in terms of biogephysical aspects Gonda Beach Area in Laliko Village Campalagian District Poliwali Mandar Regency. SPERMONDE 2(3), 25-33. 
[10] Surjanti, J., A. Soejoto, D. N. Seno, Waspodo. 2020. Mangrove forest ecotourism: Participatory ecological learning and sustainability of students' behavior through self-efficacy and selfconcept. Social Sciences \& Humanities 2(1), 100009. DOI: 10.1016/j.ssaho.2019.100009.

[11] Adamu, A., M. R. Yacob, A. Radam, R. Hashim, and S. U. Adam. 2015. Economic valuation of ecotourism resource in Yankari Game Reserve, Bauchi Nigeria. Procedia Environmental Science 30, 139-144.

[12] lasha, A., M. R. Yacob, I. Kabir, and A. Radam. 2015. Estimating economic value for potential ecotourism resource in Puncak Lawang Park, Agam District, West Sumatra, Indonesia. Procedia Environmental Science 30, 326-331.

[13] Tisca, I. A., N. Istrat., C. D. Dumitrescu, and G. Cornu. 2016. Management of sustainable development in ecotourism: Case Study Romania. Pocedia Economics and Finance 39, 427-432.

[14] Hakim, L. 2004. Dasar-dasar ekowisata. Bayumedia Publishing. Malang.

[15] Page, S. J. and R. K. Dowling. 2001. Ecotourism. Pearson Education Limited. 